\title{
Plasma and cerebrospinal fluid arginine vasopressin in patients with and without fever
}

\author{
P M Sharples, J R Seckl, D Human, S L Lightman, D B Dunger
}

\begin{abstract}
Hyponatraemia has been described in association with a number of acute infectious diseases, mainly bacterial and tuberculous meningitis and pneumonia, and has been attributed to inappropriate secretion of arginine vasopressin (AVP). The mechanism of inappropriate AVP production is uncertain, but there is experimental evidence to suggest that fever may stimulate secretion of AVP into plasma and cerebrospinal fluid. In this study, AVP concentrations in plasma and cerebrospinal fluid from 37 febrile children with infections have been compared with those from 27 afebrile control subjects. Ten of the febrile children had meningitis (eight bacterial, two viral) and the remainder a variety of other infectious diseases. Seventy four per cent of febrile infected children were hyponatraemic (serum sodium $<135 \mathrm{mmol} / \mathrm{l}$ ) compared with only $8 \%$ of the afebrile controls. Plasma AVP concentrations were significantly higher in the febrile patients (median $2.92 \mathrm{pmol} / 1$, range $1 \cdot 0-23 \cdot 25, n=28$ ) than in controls (median $1.67 \mathrm{pmol} / \mathrm{l}$, range $0.57-6.0, \mathrm{n}=14$ ) but there was no significant difference in cerebrospinal fluid AVP concentrations. There was no difference in plasma AVP concentrations between patients with meningitis and those with infections not involving the central nervous system. Careful attention should be paid to fluid and electrolyte balance in all children with acute infections.
\end{abstract}

(Arch Dis Child 1992;67:998-1002)

Department of Child Health

The Medical School,

Framlington Place, Newcastle upon Tyne NE2 4HH

P M Sharples

Department of Medicine, Western General

Hospital,

Edinburgh

J R Seckl

Department of

Paediatrics,

John Radcliffe Hospital, Oxford

D Human

D B Dunger

Department of Medicine, Charing Cross and

Westminster Medical

School,

London

S L Lightman

Correspondence to: Dr Sharples.

Accepted 10 April 1992
Hyponatraemia and water retention have been reported in children with bacterial and tuberculous meningitis, ${ }^{1-4}$ viral encephalitis ${ }^{5}$ and pneumonia. ${ }^{467}$ These findings have been attributed to inappropriate secretion of arginine vasopressin (AVP) and in a few studies plasma or cerebrospinal fluid AVP concentrations have been measured and shown to be increased. ${ }^{168}$ The mechanism of the inappropriate AVP production in these situations remains uncertain, ${ }^{8}$ although it has been suggested that increased AVP concentrations in pneumonia may be the result of intrathoracic pathology interfering with the normal modulation of AVP release via stretch and baroreceptors in the left atrium and carotid sinus. ${ }^{9}$

Experimental studies have indicated that in a variety of animal species, AVP production, hyponatraemia, and hypo-osmolality can be produced by inducing pyrexia. ${ }^{10-12}$ These observations have led to suggestions that AVP may have a role as an endogenous antipyretic. ${ }^{13} 14$
This hypothesis might explain the findings of Gonzalez et al who noted an association between hyponatraemia and a variety of acute infections. ${ }^{15}$ However, there is little published information concerning plasma or cerebrospinal fluid AVP concentrations in acute infections other than those of the central nervous or respiratory systems.

The aim of this study was to determine the concentrations of AVP in samples of plasma and cerebrospinal fluid obtained from febrile children with a variety of infectious diseases and compare these with the concentrations found in a group of afebrile control children.

\section{Patients and methods}

The study population comprised 37 febrile children with a variety of acute infectious illnesses (table 1). Ten children had meningitis (eight bacterial, two viral). The median age of the study population was 2.5 years, range 2 weeks-14 years; 20 (54\%) were boys. All the children were hospital inpatients. Samples were obtained shortly after admission at a time when venepuncture or lumbar puncture was being performed for a clinical indication. The body temperature was recorded immediately before

Table 1 Details of the febrile children

\begin{tabular}{|c|c|c|c|}
\hline $\begin{array}{l}\text { Patient } \\
\text { No }\end{array}$ & $\begin{array}{l}\text { Age } \\
\text { (years) }\end{array}$ & Sex & Diagnosis \\
\hline $\begin{array}{r}1 \\
2 \\
3 \\
4 \\
5 \\
6 \\
7 \\
8 \\
9 \\
10 \\
11 \\
12 \\
13 \\
14 \\
15 \\
16 \\
17 \\
18 \\
19 \\
20 \\
21 \\
22 \\
23 \\
24 \\
25 \\
26 \\
27 \\
28 \\
29 \\
30 \\
31 \\
32 \\
33 \\
34 \\
35 \\
36 \\
37\end{array}$ & $\begin{array}{c}10 \\
2 \cdot 5 \\
1 \cdot 5 \\
11 \\
1 \cdot 33 \\
12 \\
14 \\
5 \\
0 \cdot 75 \\
1.66 \\
1 \cdot 33 \\
1 \cdot 0 \\
3 \\
9 \\
1 \\
1 \\
0 \cdot 16 \\
0 \cdot 16 \\
11 \\
10 \\
0 \cdot 50 \\
5 \\
1 \cdot 5 \\
0.04 \\
1.75 \\
5 \\
13 \\
2.5 \\
12 \\
7 \\
9 \\
0 \cdot 25 \\
8 \\
1 \cdot 42 \\
1 \\
5 \\
7\end{array}$ & $\begin{array}{l}\mathrm{F} \\
\mathrm{F} \\
M \\
M \\
M \\
M \\
\mathrm{~F} \\
M \\
M \\
\mathrm{~F} \\
\mathrm{~F} \\
\mathrm{~F} \\
\mathrm{~F} \\
M \\
\mathrm{~F} \\
M \\
M \\
M \\
M \\
M \\
\mathrm{~F} \\
\mathrm{~F} \\
\mathrm{~F} \\
\mathrm{~F} \\
M \\
M \\
M \\
\mathrm{~F} \\
\mathrm{~F} \\
\mathbf{M} \\
\mathrm{F} \\
\mathbf{M} \\
\mathrm{F} \\
\mathrm{F} \\
\mathbf{M} \\
M \\
M\end{array}$ & $\begin{array}{l}\text { Pneumonia } \\
\text { Upper respiratory tract infection } \\
\text { Salmonella enteritis } \\
\text { Pyrexia of unknown origin } \\
\text { Viral illness } \\
\text { Urinary tract infection } \\
\text { Urinary tract infection } \\
\text { Viral illness } \\
\text { Viral illness } \\
\text { Viral illness } \\
\text { Tonsillitis } \\
\text { Cellulitis } \\
\text { Viral illness } \\
\text { Otitis media } \\
\text { Otitis media } \\
\text { Viral illness } \\
\text { Pneumonia } \\
\text { Viral illness } \\
\text { Upper respiratory tract infection } \\
\text { Osteomyelitis } \\
\text { Otitis media } \\
\text { Viral illness } \\
\text { Upper respiratory tract infection } \\
\text { Viral illness } \\
\text { Cellulitis } \\
\text { Viral illness } \\
\text { Viral illness } \\
\text { Bacterial meningitis } \\
\text { Bacterial meningitis } \\
\text { Bacterial meningitis } \\
\text { Bacterial meningitis } \\
\text { Bacterial meningitis } \\
\text { Bacterial meningitis } \\
\text { Bacterial meningitis } \\
\text { Bacterial meningitis } \\
\text { Viral meningitis } \\
\text { Viral meningitis }\end{array}$ \\
\hline
\end{tabular}


sampling. Plasma samples for AVP determination were obtained from 28 febrile children and cerebrospinal fluid samples from 19. Paired plasma and cerebrospinal fluid samples were obtained in nine of the children. No child was hypotensive or clinically dehydrated at the time of sampling.

The afebrile control population consisted of two groups, totalling 27 children: 15 children who were seen as outpatients for a variety of conditions (table 2), and from whom plasma samples were obtained, and 12 inpatients who underwent lumbar puncture for various clinical indications (table 3 ) and who provided cerebrospinal fluid samples. The median age of the control population was 7.0 years, range 1 month-15 years; $13(48 \%)$ were boys. There was no significant difference between the age structure of the study and control groups (Mann-Whitney U test, $\mathrm{p}=0 \cdot 13)$.

Blood $(0.5-1.0 \mathrm{ml})$ was taken onto ice, centrifuged immediately, and the plasma separated and stored at $-20^{\circ} \mathrm{C}$ until assay. Cerebrospinal fluid $(0.5 \mathrm{ml})$ was also taken onto ice and stored at $-20^{\circ} \mathrm{C}$. Immediately before AVP assay, the plasma sample was extracted through octadecasilyl silica cartridges (Sep-pak C18, Waters Associates). The AVP concentration in plasma and cerebrospinal fluid was measured by radioimmunoassay, as described previously. ${ }^{16}$ The intra-assay coefficient of variation was $5 \%$ and the interassay coefficient of variation $15 \%$. The limit of detection of the assay was 0.30 $\mathrm{pmol} / \mathrm{l}$. In the data analysis, a non-detectable concentration of AVP was assigned a value of $0.00 \mathrm{pmol} / \mathrm{l}^{8}$

The study was approved by the local ethical committee.

Table 2 Details of the afebrile children who provided plasma samples

\begin{tabular}{llll}
\hline $\begin{array}{l}\text { Patient } \\
\text { No }\end{array}$ & $\begin{array}{l}\text { Age } \\
\text { (years) }\end{array}$ & Sex & Diagnosis \\
\hline 1 & 4 & M & Asthma \\
2 & $0 \cdot 25$ & F & Skeletal dysplasia \\
3 & $0 \cdot 83$ & M & Constipation \\
4 & $0 \cdot 04$ & M & Feeding difficulties \\
5 & 10 & B & Bell's palsy \\
6 & 5 & F & Asthma th thrive \\
7 & 2 & M & Failure to thre \\
8 & 1 & M & ?Breath holding attacks ?Fits \\
9 & 8 & F & Acute leukaemia \\
10 & 14 & M & Constitutional short stature \\
11 & 12 & F & Friedreich's ataxia \\
12 & 13 & M & Constitutional short stature \\
13 & $0 \cdot 75$ & F & Failure to thrive \\
14 & 15 & M & Constitutional short stature \\
15 & 12 & F & Diabetes mellitus \\
\hline
\end{tabular}

Table 3 Details of the afebrile children who provided cerebrospinal fluid samples

\begin{tabular}{lcll}
\hline $\begin{array}{l}\text { Patient } \\
\text { No }\end{array}$ & $\begin{array}{l}\text { Age } \\
\text { (years) }\end{array}$ & Sex & Diagnosis \\
\hline 1 & $0 \cdot 02$ & F & ?Seizure \\
2 & $0 \cdot 58$ & M & Seizures \\
3 & 14 & H & Headache ?meningitis \\
4 & 13 & F & Staging for acute leukaemia \\
5 & 10 & F & Staging for acute leukaemia \\
6 & 11 & N & Neck stiffness ?meningitis \\
7 & 11 & Guillain-Barré syndrome \\
8 & 5 & M & Epilepsy \\
9 & 9 & F & Headache ?meningitis \\
10 & 4 & Staging for acute leukaemia & Staging for non-Hodgkin's lymphoma \\
11 & 7 & F & Staging for acute leukaemia \\
\hline
\end{tabular}

\section{Results}

Figure 1 shows the plasma AVP results obtained in febrile and afebrile patients. The plasma AVP concentrations obtained from the febrile children (median $2 \cdot 92 \mathrm{pmol} / \mathrm{l}$, range $1 \cdot 00-23 \cdot 25$ ) were significantly higher than those obtained from the afebrile controls (median $1.67 \mathrm{pmol} / 1$, 0.57-6.0) (Mann-Whitney $U$ test, $p=0.003$ ). The difference between febrile and afebrile subjects persisted if children with meningitis were excluded from the analysis (median plasma AVP concentration among febrile, nonmeningitic patients $2.49 \mathrm{pmol} / \mathrm{l}$, range 1.0-23.25) (Mann-Whitney $U$ test, $p=0.036$ ). Plasma AVP concentrations in the meningitic children (median $4 \cdot 14 \mathrm{pmol} / \mathrm{l}$, range $1 \cdot 16-15 \cdot 25$, $\mathrm{n}=6$ ) were not in fact significantly different from those observed in the other febrile children (Mann-Whitney $U$ test, $p=0 \cdot 10$ ). There was no difference in plasma AVP concentrations according to sex, either when all the patients were considered together (Mann-Whitney $\mathrm{U}$ test, $\mathrm{p}=0 \cdot 10)$ or in the febrile and afebrile subgroups. There was also no correlation between plasma AVP concentration and age $(r=$ $-0.06, \mathrm{p}=0.70$ ).

There was no significant difference between the cerebrospinal fluid AVP concentrations obtained from the febrile study children (median

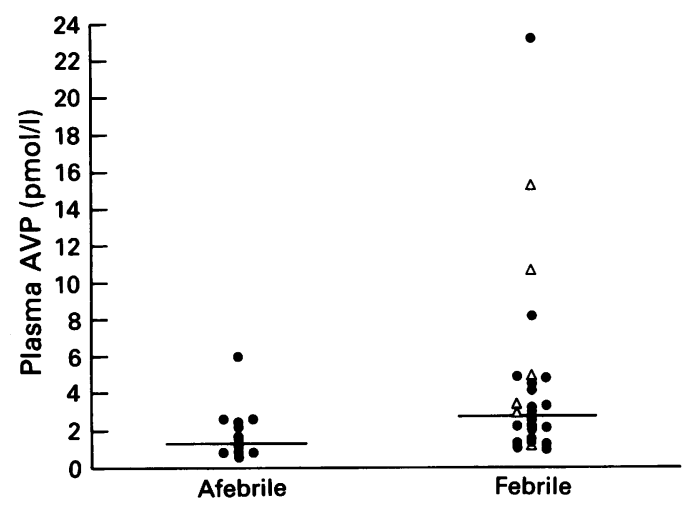

Figure 1 Plasma AVP concentrations (pmol/l) in febrile children with acute infections compared with febrile control children. Among the febrile children, the triangular symbols represent those with bacterial or viral meningitis and the circular symbols, those with other acute infections.

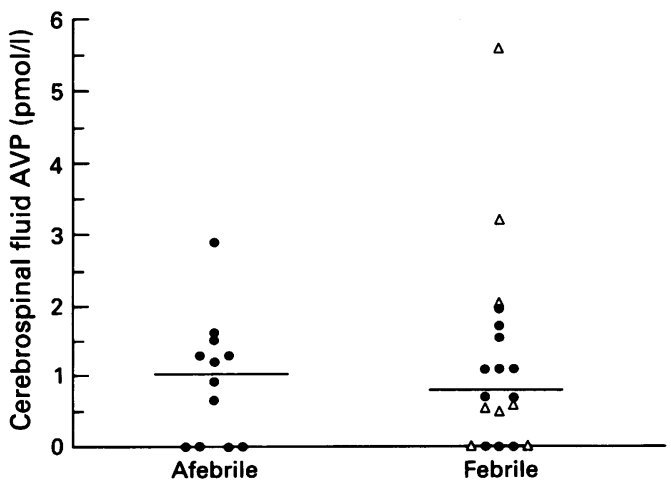

Figure 2 Cerebrospinal fluid AVP concentrations (pmol/l) in febrile children with acute infections compared with afebrile control children. Among the febrile children, the triangular symbols represent those with bacterial or viral meningitis and the circular symbols, those with other acute infections. 
$0.7 \mathrm{pmol} / \mathrm{l}$, range $0-5.57)$ and those obtained from the afebrile control children (median 1.06 $\mathrm{pmol} / \mathrm{l}$, range 0-2.9) (Mann-Whitney $U$ test, $\mathrm{p}=0.38$ ) (fig 2). There was also no significant difference between the AVP cerebrospinal fluid concentrations obtained from children with meningitis (median $0.56 \mathrm{pmol} / \mathrm{l}$, range $0-5.57$, $\mathrm{n}=8$ ) and those obtained from other febrile children (median $0.90 \mathrm{pmol} / \mathrm{l}$, range $0-1.98$, $\mathrm{n}=10$ ) (Mann-Whitney $\mathrm{U}$ test, $\mathrm{p}>0.05$ ). As with the plasma results, no correlation was found between cerebrospinal fluid AVP concentration and age $(r=0.22, \mathrm{p}=0 \cdot 10)$ and there was also no significant difference in the results obtained from boys and girls (Mann-Whitney $\mathrm{U}$ test, $\mathrm{p}=0 \cdot 24)$.

Figure 3 illustrates the relationship between body temperature and plasma AVP concentrations in the febrile children. There was no correlation between body temperature and plasma AVP concentration $(r=0 \cdot 09), \mathrm{p}>0 \cdot 05)$. There was also no correlation between body temperature and cerebrospinal fluid AVP concentration (fig 4) $(r=0.23, p>0.05)$. Among the nine children from whom paired plasma and

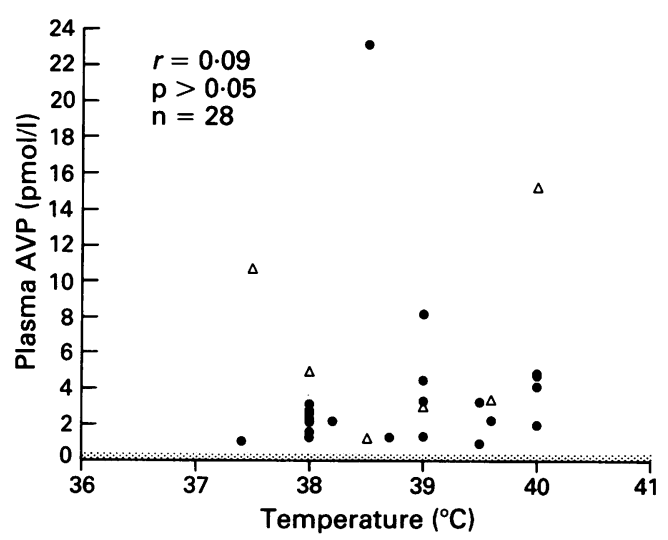

Figure 3 Relationship between body temperature and plasma AVP concentration ( $p$ molll) for the 28 febrile children from whom plasma samples were obtained. The triangular symbols represent children with bacterial or viral meningitis and the circular symbols represent children with other acute infections.

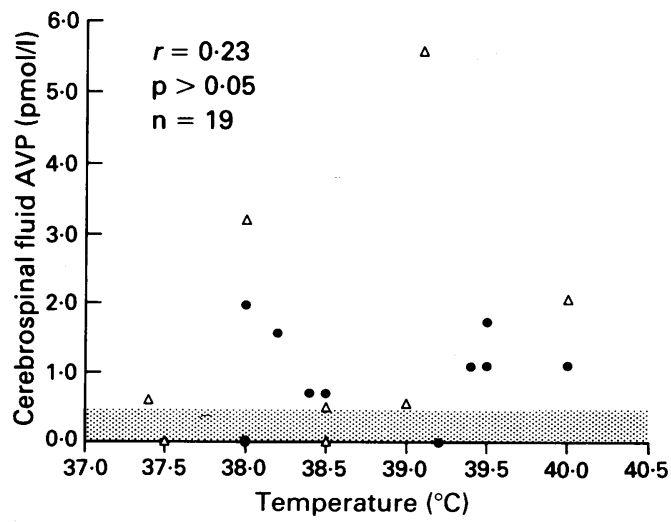

Figure 4 Relationship between body temperature and cerebrospinal fluid AVP concentration (pmol/l) for the 19 febrile children from whom cerebrospinal fluid samples were obtained. The triangular symbols represent children with bacterial or viral meningitis and the circular symbols represent children with other acute infections. The shaded area indicates the lower limit of detection of the assay. cerebrospinal fluid samples were obtained, there was no significant correlation between plasma and cerebrospinal fluid AVP concentrations $(r=$ $0 \cdot 32, \mathrm{p}=0.40$ ).

Serum sodium concentrations, obtained concomitantly, were available for $23 / 37(62 \%)$ febrile study patients and 12/27 (44\%) afebrile control children. The serum sodium concentrations observed in febrile children (median 132 $\mathrm{mmol} / \mathrm{l}$, range 129-140) were significantly lower than those in the 12 afebrile study children (median $138 \mathrm{mmol} / \mathrm{l}$, range 133-143) (MannWhitney $U$ test, $p=0.002$ ). There were $17 / 23$ $(74 \%)$ febrile children who were hyponatraemic (serum sodium concentration less than 135 $\mathrm{mmol} / \mathrm{l}){ }^{4}$ whereas only one afebrile control child was hyponatraemic. Six (35\%) of the hyponatraemic febrile children had meningitis but the remaining 11 had other acute infections. There was no significant difference between the serum sodium results obtained from the children with meningitis (median $132 \mathrm{mmol} / \mathrm{l}$, range 131-139, $\mathrm{n}=7$ ) and those obtained from the other febrile children (median $133 \mathrm{mmol} / \mathrm{l}$, range 129-140, $n=16$ ) (Mann-Whitney $U$ test, $\mathrm{p}=0 \cdot 33$ ). There was no correlation between serum sodium concentration and plasma AVP concentration in the febrile children $(r=0.04$, $p>0.50$ ) nor between serum sodium and cerebrospinal fluid AVP concentration $(r=0.46$, $\mathrm{p}=0 \cdot 18$ ).

\section{Discussion}

The results of this study demonstrate that increased plasma concentrations of AVP occur not only in children with bacterial meninigitis, viral encephalitis and pneumonia, as previously reported, but also in association with a wide range of other acute infections. The occurrence of detectable plasma concentrations of AVP in children with low serum sodium results $(<135$ $\mathrm{mmol} / \mathrm{l}$ ) confirms the inappropriate nature of the AVP secretion. Hyponatraemia has been previously described in acutely febrile children, ${ }^{15}$ and there have been a number of isolated case reports reporting inappropriate AVP secretion in tetanus, ${ }^{17}$ viral meningitis, ${ }^{18}$ and Rocky Mountain spotted fever ${ }^{19}$ However, no previous study has demonstrated increased AVP production in such a variety of acute infections.

None of the children in this study were on treatment recognised to be associated with increased AVP production, such as vincristine, chlorpropramide, tricyclic antidepressants, or phenothiazines. ${ }^{9}$ Increased AVP production may occur in response to pain or anxiety,, 2021 and increased concentrations in unanaesthetised children might in part reflect the stress associated with venepuncture or lumbar puncture in this age group. However, there seems no reason to suppose that this effect would be confined to the study children, particularly as the age structure of the study and control groups was similar.

In this study, there was a significant difference between plasma AVP concentrations from febrile and afebrile patients, but no significant difference in the cerebrospinal fluid AVP concentrations between study and control groups. It is 
possible that this may reflect the difficulty of establishing 'control' cerebrospinal fluid values in a paediatric population. There were $5 / 12$ (42\%) afebrile control children who underwent lumbar puncture because of an actual or suspected abnormality of the central nervous system (table 3) and increased cerebrospinal fluid AVP concentrations have been described in association with a variety of non-infectious central nervous system pathologies. ${ }^{16} 22-25$ Another methodological consideration is the fact that it was not possible to standardise the time of day at which the samples were obtained; discrepancies in the sampling times might therefore have obscured differences between groups in the cerebrospinal fluid AVP concentrations. ${ }^{26}$ However, no diurnal rhythm of AVP cerebrospinal fluid concentration has been demonstrated in humans. ${ }^{27}$ Moreover, it is recognised that under physiological conditions, AVP concentrations in cerebrospinal fluid and blood are differentially regulated $^{26}$ and that various stimuli which increase plasma AVP concentrations may produce little alteration in cerebrospinal fluid levels. ${ }^{28}$ Even when stimulatory effects are found, AVP release into cerebrospinal fluid has a greater threshold than release into blood. ${ }^{26}$ In the nine cases in this study, in whom paired blood and cerebrospinal fluid samples were available, there was no correlation between plasma and cerebrospinal fluid AVP concentrations. Indeed, it has been suggested that the increased AVP concentrations in cerebrospinal fluid described in meningitic children are the result of leakage from the circulation across a damaged blood-brain barrier, rather than the result of increased intracerebral production, ${ }^{8}$ and this hypothesis would be in keeping with our observations.

The results of this study do not give any indication of the pathogenetic mechanism responsible for the increased plasma concentrations of AVP. The lack of correlation between body temperature and plasma and cerebrospinal fluid AVP concentrations is in contrast to the results of some experimental studies, in which a relationship between pyrexia and AVP production has been demonstrated, ${ }^{12} 14$ but in agreement with the results of others, in which a direct correlation was not found. ${ }^{10} 12$ It may be that, in some species, fever has an 'all or nothing' effect on AVP production or that a single temperature measurement does not reflect accurately the degree of stimulus to AVP secretion. Alternatively, the mechanism of the increased AVP production in children with acute infections may be unrelated to the occurrence of fever; certainly, there is experimental evidence to suggest that the role of AVP as an antipyretic may vary between species. ${ }^{29} 30$ Increased plasma concentrations of AVP have been described in burned children ${ }^{31}$ and in postoperative paediatric surgical patients, ${ }^{32}$ and it has been suggested that the increased concentrations probably represent part of the body's stress response. ${ }^{9} 32$ Increased AVP production in acute infections may occur for the same reason. ${ }^{33}$

The finding that inappropriate AVP production and hyponatraemia is not an uncommon phenomenon in febrile children with a variety of acute infections indicates that the serum sodium concentration should always be determined before administering intravenous fluid in such patients. The significance of the inappropriate AVP production, in terms of implications for outcome, is uncertain and was not explored in this study. Among children with bacterial meningitis, both the degree of hyponatraemia on admission and its duration seem to correlate with long term outcome ${ }^{34}$ and this has been attributed to the effect of AVP on brain water permeability and cerebral oedema. ${ }^{35}$ Although this may seem at first to have little relevance to children with infections not involving the central nervous system, it has been suggested that AVP has a role in the pathogenesis of febrile convulsions through its effect on brain water permeability. ${ }^{36}$ In this study, eight children (median age 1.6 years, range $1 \cdot 0-5$ ) underwent lumbar puncture after a presumed febrile convulsion; there was no significant difference in the plasma or cerebrospinal fluid AVP concentrations obtained from these children and those obtained from febrile children in the age group at risk from febrile convulsions (6 months -6 years ${ }^{37}$ ) who did not have convulsions (Mann-Whitney U test: $p=0.10$ for plasma; $\mathrm{p}=\mathbf{0 . 0 8}$ for cerebrospinal fluid). However, in view of the small numbers, further studies would be necessary to explore this issue and to investigate the relationship between AVP production and hyponatraemia and eventual outcome in febrile infected children.

We would like to acknowledge all the medical and nursing staff at the John Radcliffe Hospital who assisted with the sample collection and Drs J Kay, A Foot, and P Holland for their help. JRS is a Wellcome Senior Fellow in Clinical Science.

1 Kaplan SL, Feigin RD. The syndrome in inappropriate secretion of antidiuretic hormone in children with bacterial secretion of antidiuretic hormone in child
meningitis. $\mathcal{f}$ Pediatr 1976;88:542-8.

2 Reynolds DW, Dweck HS, Cassady G. Inappropriate antidiuretic hormone secretion in a neonate with meningitis. diuretic hormone secretion in a
Am $\mathcal{F}$ Dis Child 1972;123:251.

3 Smith J, Godwin-Austin R. Hypersecretion of anti-diuretic hormone due to tuberculous meningitis. Postgrad Med $\mathcal{J}$ 1980;56:41-4.

4 Shann F, Germer S. Hyponatraemia associated with pneumonia or bacterial meningitis. Arch Dis Child 1985;60: 963-6.

5 Rovitt RL, Sigler MH. Hyponatraemia with herpes simplex encephalitis. Arch Neurol 1964;101:595-603.

6 Rivers RPA, Forsling ML, Olver RP. Inappropriate secretion of antidiuretic hormone in infants with respiratory infections. Arch Dis Child 1981;56:358-63.

7 Rosenow EC, Segar WE, Zehr. Inappropriate antidiuretic hormone secretion in pneumonia. Mayo Clin Proc 1972;47: 169-74.

8 Garcia H, Kaplan SL, Feigin RD. Cerebrospinal fluid concentration of arginine vasopressin in children with bacterial centration of arginine vasopressin in children with bacterial meningitis. F Pediatr 1981;98:67-70.

9 Weise K, Zaritsky A. Endocrine manifestations of critical illness in the child. Pediatr Clin North Am 1987;34:119-30.

10 Szczepanska-Sadowska E. Plasma ADH increase and thirst suppression elicited by preoptic heating in the dog. $A m \mathcal{F}$ Physiol 1974;226:155-61.

11 Kruk B, Sadowski J. Antidiuretic action of intravenous and intracerebral pyrogen in conscious rabbits. $\mathcal{F}$ Physiol 1978; 282:429-35.

12 Kasting NW, Carr DB, Martin JB, Blume H, Bergland R. Changes in cerebrospinal fluid and plasma vasopressin in the febrile sheep. Can Physiol Pharmacol 1983;61:427-31.

13 Cooper KE, Kasting NW, Lederis K, Veale WL. Evidence supporting a role for endogenous vasopressin in natural supporting a role for endogenous vasopressin in natural
suppression of fever in the sheep. $\mathcal{F}$ Physiol 1979;295: $33-45$.

14 Naylor AM, Cooper KE, Veale WL. Vasopressin and fever: evidence supporting the existence of an endogenous antievidence supporting the existence of an endogenous anti-
pyretic system in the brain. Can $\mathcal{F}$ Physiol Pharmacol 1987; 65:1333-8.

15 Gonzalez CF, Finberg L, Bluestein DD. Electrolyte concentration during acute infections. Am $\mathcal{F}$ Dis Child 1964;107: 476-82.

16 Seckel J, Lightman S. Cerebrospinal fluid neurohypophysial 
peptides in benign intracranial hypertension. $\mathcal{F}$ Neurol Neurosurg Psychiatry 1988;51:1538-41.

17 Potgieter PD. Inappropriate ADH secretion in tetanus. Crit Care Med 1983;11:417-8.

18 Chemtob S, Reece ER, Mills EL. Syndrome of inappropriate secretion of antidiuretic hormone in enteroviral meningitis. Am f Dis Child 1985;139:292-4.

19 Sexton DJ, Clapp J. Inappropriate antidiuretic hormone secretion. Occurrence in a patient with Rocky Mountain secretion. Occurrence in a patient with Rocky
spotted fever. Arch Intern Med 1977;137:362-3.

20 Clinch D. Syndrome of inappropriate antidiuretic hormone secretion associated with stress. Lancet 1982;i:1131-2.

21 Kaplan SL, Feigin RD. Syndromes of inappropriate secretion of ADH. Year book of paediatrics. Chicago: Year Book Medical, 1980:247-74

22 Sorensen PS, Gjerris A, Hammer M. Cerebrospinal fluid vasopressin in neurological and psychiatric disorders. f Neurol Neurosurg Psychiatry 1985;48:50-7.

23 Sorensen PS, Gjerris F, Hammer M. Cerebrospinal fluid vasopressin and increased intracranial pressure. Brain Res 1978;143:191-4.

24 Mather HM, Ang V, Jenkins JS. Vasopressin in plasma and CSF of patients with subarachnoid haemorrhage. $\mathcal{F}$ Neurol Neurosurg Psychiatry 1981;44:216-9.

25 Davies AG. Inappropriate secretion of antidiuretic hormone in Guillain-Barré syndrome. Postgrad Med $\mathcal{F}$ 1971;47: in Guilla

26 Reppert SM, Schwatz WJ, Uhl GR. Arginine vasopressin: a novel peptide rhythm in cerebrospinal fluid. Trends in Neurosciences 1987;10:76-80.

27 Amico JA, Tenicela R, Robinson AG. 7 Clin Endocrinol Metab 1985;61:794-98.
28 Robinson ICAF. In: Cross BA, Leng G, eds. The neurohypophysis: structure, function and control (Progress in Brain Research). Amsterdam: Elsevier, 1983;60:129-45.

29 Bernardini GL, Lipton JM, Clark WG. Intracerebronventricular and septal injections of arginine vasopressin are not antipyretic in the rabbit. Peptides 1983;4:195-8.

30 Lee TF, Mora F, Myers RD. Effect of intracerebronventricular vasopressin on body temperature and endotoxin fever of vasopressin on body temperature and endotox

31 Stark H, Weinberger AH, Ben-Basset M. Persistent hyponatremia and inappropriate antidiuretic hormone secretion in children with extensive burns. F Pediatr Surg 1979;14: in children

32 Burrows FA, Shitack JG, Crone RK. Inappropriate secretion of antidiuretic hormone in a postsurgical paediatric population. Crit Care Med 1983;11:527-31.

33 Beisel WR, Sawyer WD, Ryll ED, Crozier D. Metabolic effects of intracellular infections in man. Ann Intern Med 1967;67:744-79.

34 Feigin RD, Kaplan S. Inappropriate secretion of antidiuretic hormone in children with bacterial meningitis. Am $\mathcal{F}$ Clin Nutr 1977:30:1482-4.

35 Raichle ME, Grubb RL. Regulation of brain water permeability by centrally released vasopressin. Brain Res 1978; 143:191.

36 Kasting NW, Veale WL, Cooper KE, Lederis K. Vasopressin may mediate febrile convulsions. Brain Res 1981;213: 327-33.

37 Brett EM. Epilepsy and convulsions. In: Brett EM ed. Paediatric neurology 2nd Ed. London: Churchill Livingstone, 1991:317-88.

\section{Maternal chickenpox}

Maternal chickenpox in early pregnancy has been associated with abnormalities in the fetus including microphthalmia, cataracts, Horner's syndrome, microcephaly, and growth defects of limbs, fingers, and muscles. Congenital varicella syndrome was found in three of 61 patients $(5 \%)$ in three previously reported studies. Now another 40 mothers with first trimester chickenpox have been reported from Connecticut (James Balducci and colleagues, Obstetrics and Gynecology 1992;79:5-6). One mother elected for termination of pregnancy and three had spontaneous abortions. There is no comment about abnormality in these fetuses. One fetus was shown by ultrasound examination to have a large omphalocele and the pregnancy was terminated. None of the pregnancies was complicated by congenital varicella syndrome as previously described.

Maternal chickenpox is not common because most mothers have had the disease in childhood. These authors quote an incidence of 0.7 per thousand pregnancies but it is not clear whether that figure is for chickenpox at any stage in pregnancy or just the first trimester. In any event congenital varicella syndrome is rare but it should disappear altogether with chickenpox immunisation (see Archivist 1991:1212). 